\title{
AMÉLIA FERNANDES DA COSTA: TRAJETÓRIA BIOGRÁFICO-PROFISSIONAL
}

\section{HELOISA HELENA MEIRELLES DOS SANTOS}

Universidade do Estado do Rio de Janeiro

RESUMO Estabelecer a trajetória biográfico-profissional da professora primária Amélia Fernandes da Costa, formada pela Escola Normal da Corte, para entender as razões que a levaram a ser escolhida, em 1890, dentre os demais professores primários públicos da capital do Brasil, para empreender viagem pedagógica subsidiada pela Instrução Pública à Europa, é o objetivo deste artigo. A pesquisa baseia-se no paradigma indiciário de Ginzburg (1989) tomando por fontes privilegiadas documentos localizados no Centro de Memória do Instituto Superior de Educação do Rio de Janeiro, ainda não investigados pela historiografia; Relatórios Ministeriais do Império, disponibilizados no Center for Research Libraries; e jornais de época, do acervo da Biblioteca Nacional brasileira. A investigação pretende minimizar lacuna biográfica sobre a professora Amélia Fernandes da Costa.

Palavras-chave: Amélia Fernandes da Costa. Trajetória biográfico -profissional. Escola Normal da Corte.

\section{ABSTRACT AMÉLIA FERNANDES DA COSTA: BIOGRAPHICAL - PROFESSIONAL TRAJECTORY}

To establish the biographical-professional trajectory of the primary teacher Amélia Fernandes da Costa, formed by the Escola Normal da Corte, to understand the reasons that led her to be chosen in 1890 from among the other primary public teachers in the Brazilian capital to undertake a pedagogical trip subsidized by the Instrução Pública to Europe, is the objective of this article. The research is based on Ginzburg's (1989) indicium paradigm, taking as privileged sources documents located in the Centro de Memória do Instituto Superior de Educação do Rio de Janeiro, not yet investigated by the historiography; Ministerial Reports of the Empire, available in the Center for Research Libraries; and periodicals of the collection of the Brazilian National Library. It intends the research to minimize biographical gap on the teacher Amélia Fernandes da Costa.

Keywords: Amélia Fernandes da Costa. Biographical-professional trajectory. Escola Normal da Corte. 


\section{RESUMEN AMELIA FERNANDES DA COSTA: TRAYECTORIA BIOGRAFICO-PROFESIONAL}

Establecer la trayectoria biográfico-profesional de la maestra Amélia Fernandes da Costa, de la Escola Normal da Corte, para comprender las razones que la llevaron a ser elegida, en 1890, entre las demás maestras públicas de la capital brasileña, para emprender una viaje subvencionada por la educación en Europa, es el objetivo de este artículo. La investigación se basa en el paradigma indicium de Ginzburg (1989), tomando como fuentes privilegiadas los documentos ubicados en el Centro de Memória do Instituto Superior de Educação do Río de Janeiro, que aún no ha sido estudiado por el la historiografia; informes departamentales del Imperio, disponibles en el Center for Research Libraries; y publicaciones periódicas e de la colección de la Biblioteca Nacional brasileña. Se espera que la investigación minimice la brecha biográfica con respecto a la maestra Amélia Fernandes da Costa.

Palabras clave: Amelia Fernandes da Costa. Trayectoria biográfico -profesional. Escola Normal da Corte.

\section{Uma viajante desconhecida}

[...] o número de viajantes mulheres, em relação ao de autores homens, já é indicativo de um padrão - o espaço para as mulheres, em viagens longas e perigosas, que não existia no início do século XIX, foi conquistado muito lentamente com a modernização dos transportes marítimos, mas conservou-se área predominantemente masculina. (LEITE, 1997, p. 16)

Ensina Kehl (2008) que "as mulheres enquanto sujeitos, só podem ser pensadas em referência ao que seriam: ao homem, à posição masculina e à masculinidade" (2008, p. 11), deste modo, penso em Amélia Fernandes da Costa, professora do século XIX, falecida no século seguinte, no que era, enquanto profissional, em um momento histórico onde ser professora relacionava a educação dos filhos, única da mulher daquele momento, à instrução. Tempo em que as Escolas Normais duravam pouco, por falta de recursos dos cofres provinciais, e a "escola doméstica, cuida[va], ampara[va], ama[va] e educa[va]" (ALMEIDA, 2004, p. 1). Momento onde "se [construía] a tessitura mulher-mãe-professora [...] que ilumina[va] na senda do saber a moralidade [...]" (ALMEIDA, 2004, p. 1), o que não se modifica nos primeiros tempos de mudança do regime político brasileiro.

Quem foi Amélia Fernandes da Costa, professora indicada, entre professores homens, para empreender viagem pedagógica comissionada à Europa, nos primeiros anos do regime republicano? Todos os pesquisadores que estudaram seus relatórios de viagem, ou a citaram como integrante de um grupo de viajantes comissionados pela Instrução Pública em 1890, alegaram não poder conhecê-la. Quem foi esta profissional viajante? Importante determinar que as viagens pedagógicas de Amélia Fernandes da Costa à Itália, França e Bélgica e de seus companheiros, Luiz Augusto dos Reis (a Portugal, Espanha, França e Bélgica) e Manuel Pereira Frazão (à Itália, Suiça, Suécia, Bélgica, Inglaterra e França), foram objeto de várias in-

1 Obedecida a grafia da fonte. 
vestigações de historiadores que tomaram por fonte os relatórios de viagem destes docentes, veiculados pela Revista Pedagogica, ${ }^{2}$ ou publicados por editores, que publicizaram e fizeram circular as impressões destes professores primários aos lugares visitados. Entre estas investigações destaco: Conceição (2018), Mignot e Silva (2011), Garcia (2011), Pinto (2011), Schueler e Gondra (2010), Schueler (2007) e Gerbovic (2007), dentre outros historiadores.

A professora Amélia Fernandes da Costa fez parte do grupo de viajantes que incluía Adelina Doyle e Silva, e deveria conhecer modelos pedagógicos europeus que pudessem aprimorar o ensino público no Distrito Federal, com uso de novas práticas e métodos pedagógicos. Adelina desistiu da viagem antes de empreendê-la, mas os demais escolhidos partiram e elaboraram relatórios de suas experiências que foram publicados "[registrando] os serviços dos distinctos comissionados, para que formem brilhante pagina na historia do nosso magisterio publico primário", na revista do Pedagogium (REVISTA PEDAGÓGICA, Tomo II, 1891, p. 252). ${ }^{3}$ Com estes professores primários estavam, também, segundo Schueler e Gondra (2010), docentes de outras instituições - da Faculdade de Medicina do Rio de Janeiro, da Escola Politécnica, do Ginásio Nacional, do Instituto Benjamin Constant e do Instituto Nacional de Música -, que embarcaram com os mesmos objetivos: tomar como referencial de instrução os modelos "civilizados", dentro de suas respectivas áreas de trabalho.

Os membros da comissão distinguiam-se daqueles que viajam por 'puro prazer ou amor à cultura'. Viajavam na e pela condição de professor, cabendo-lhes uma série de atribuições e encargos que outros viajantes não enfrentavam. Profissio-

2 A Revista Pedagógica era uma publicação do Pedagogium que todas as escolas públicas na Corte, e depois no Distrito Federal, recebiam periodicamente. Para saber mais, ver: GONDRA, José Gonçalves. O Veículo de Circulação da Pedagogia Oficial da República: a Revista Pedagógica. Brasil. Est. Pedagógicos, Brasília, v. 78, n. 188; 189; 190, p. 374-395, jan./dez 1997.

3 Obedecida a grafia da fonte. nais comissionados deveriam visitar as escolas, observar e estudar os métodos, técnicas e arquitetura de locais de ensino, escrever relatórios descrevendo tudo, além de remeter os materiais e objetos interessantes para o ensino no Brasil. Tais atribuições sugerem pensar a viagem em missão oficial como parte de uma troca entre os envolvidos, no sentido de dom e contradom, uma vez que, se, por um lado, recebia-se financiamento e custeio de hospedagem e deslocamentos, por outro, havia uma série de obrigações e encargos, no sentido de retribuir aqueles que financiavam a viagem. (MIGNOT; SILVA, 2011, p. 437)

Não é nosso objetivo, na pesquisa, enveredar pela viagem da professora Amélia Fernandes da Costa, já fartamente descrita pela historiografia, há cerca de uma década, mas saber quem era esta mulher desconhecida pela historiografia, que foi escolhida, dentre outras, na rede de professores primários da capital federal, para esta turnê comissionada, a primeira da república, e estabelecer hipóteses sobre o porquê foi ela escolhida para esta missão. Amélia foi mencionada, e seus relatórios citados em todas as investigações realizadas sobre estas viagens, por pesquisadores que afirmaram desconhecer sua biografia, ainda que, no momento daquelas pesquisas, tenham sido consultadas várias obras de referência.

Impus-me o desafio de rastrear a vida de Amélia, em busca de pistas, indícios ou sinais (GINZBURG, 1989), buscando outras fontes não usadas nas pesquisas daqueles historiadores: jornais da época, Relatórios da Instrução Pública e documentos acadêmicos. Enfim, narrar o que me fosse possivel descobrir, adentrando a "[...] porta [...] escancarada [...] oferecida a todos, em revisitações sempre possíveis das efrações individuais e de seus traços no tempo" (DOSSE, 2009, p. 410), optando por trilhar o caminho historiográfico do paradigma indiciário, ousando comparar-me a um "detetive que descobre o autor do crime baseado em indícios imperceptíveis para a maioria" (GINZBURG, 1989, p. 144- 145). 
Pelo Diário Comercial de 26 de maio de 1890, à p. 1, pude saber que Amélia foi vice-provedora da Irmandade do Divino Espírito Santo do Convento das Carmelitas (Diário Comercial, 26 de maio de 1890, p. 1), ${ }_{4}^{4}$ o que me permitiu analisar este momento em que a Igreja católica regrava as normas de conduta feminina, ao mesmo tempo que distinguia, nas irmandades leigas, o papel social de quem as integrava. Seguindo o método indiciário, sobre a viagem de Amélia, acrescento aos estudos já realizados, e amplamente difundidos, o que pude descobrir: que as viagens de Amélia Fernandes da Costa proporcionaram à Instrução Pública primária na cidade do Rio de Janeiro uma exposição no Pedagogium, em 1892, com mostra dos objetos trazidos por ela das escolas visitadas na Europa (Gazeta da Tarde, 4 de janeiro de 1892, p. 2) e a produção de dois livros de sua autoria “O Ensino Público Primário na Itália, França e Bélgica", editado pela Imprensa Nacional, em 1893, e "Lições de Cousas", com as apropriações do método intuitivo por Amélia, que foi “aprovado e adotado nas escolas públicas primárias, [em 1897], pelo Conselho de Instrução, [por estar] de acordo com os novos preceitos pedagógicos" (Gazeta da Tarde, 23 de novembro de 1897, p. 1), obra que foi remetida, como estratégia de publicização da autora, aos principais jornais em circulação naquele momento na cidade do Rio de Janeiro.

Os jornais também visibilizam que Amélia não viajou sozinha (Gazeta da Tarde, 20 de junho de 1891, p. 2), tendo sido acompanhada por João Francisco da Costa Júnior, seu marido, que solicitou inicialmente licença de seis meses do trabalho que realizava na Alfândega do porto do Rio de Janeiro (Jornal do Commercio, 7 de maio de 1891, p. 1) e depois, mais seis meses, obtendo de sua chefia apenas uma prorrogação de dois meses da licença inicial (Jornal do Com-

4 João Francisco, marido de Amélia, foi procurador da Caixa Emancipadora de Nossa Senhora da Glória (Gazeta de Notícias, 7 de abril de 1884, p. 1). mercio, 8 de maio de 1891, p. 10), para acompanhá-la. Acredito que este procedimento de viajar acompanhada não tenha ocorrido apenas pelo fato de Amélia ser mulher casada e necessitar, sempre, pelos valores da época, estar acompanhada, pois também pude verificar que o professor Luiz Augusto do Reis viajou com a família, inclusive seus filhos (Diário do Commercio, 23 de junho de 1891, p. 3). E, aqui, cabe lembrar que as mulheres viajantes no século XIX, no contato com "nações livres e civilizadas, [ainda carregavam] experiências relativas à submissão das mulheres" (MAIA, 2014, p. 63).

\section{Trajetória biográfico-profissional}

[...] Meu pai tinha um superior na Alfândega ${ }^{5}$, cuja esposa era professora na Rua da Quitanda6. Ao saber do sucedido, propôs que eu fosse para aquela escola. Fui. Ali, D. Amélia Fernandes da Costa me deu provas do que podem uma grande mestra e um coração de mulher. Fui um dos aprovados, com distinção, no exame final ${ }^{7}$ realizado na Benjamin Constant; tão miúdo, ainda, que precisava alcançar o alto do quadro-negro na ponta dos pés, provocando gargalhadas dos examinadores. Ao terminar o primário, ela, diante da pobreza de meu pai, se prontificou a me ajudar para que pudesse fazer o secundário. Consegui matrícula gratuita e continuei o meu rosário de distinções. Pois D. Amélia, ainda que sentindo imensa alegria, nunca me fez um elogio. Jamais ouvi dela palavra de louvor. Nem era preciso. Seu olhar dizia tudo [...]. (BLOCH ENTREVISTA ANTENOR NASCENTES apud MIGNOT; SILVA, 2011, p. 440)

A rememoração em epígrafe, pouco informa biograficamente sobre a professora Amélia, pois além da impressão pessoal do memoria-

5 Era João Francisco da Costa Júnior escriturário da Alfândega.

6 Não encontrei nenhum documento que constasse existir ali, desde a criação do educandário, classe mista, o que me leva a supor que Antenor Nascentes não estivesse regularmente matriculado, por não pertencer ao gênero atendido no educandário e fosse ouvinte, o que não o impediria de fazer o Exame final na Benjamin Constant, ou assistir às aulas de Amélia.

70 exame final era realizado pela Instrução Pública. 
lista de que Amélia nunca proferia um elogio e, pelo olhar, parecia alegre pelo desempenho de seus alunos, pouco comenta sobre ela. No entanto, a lembrança de Antenor Nascentes forneceu-me um pequeno indício: a escola onde Amélia regia turmas era na Rua da Quitanda.

E como "por milênios o homem foi caçador [...] durante inúmeras perseguições, ele aprendeu a reconstruir as formas e movimentos das presas invisiveis pelas pegadas na lama, ramos quebrados" (GINZBURG, 1989, p 151), pelo Almanack Laemmèrt, verifiquei tratar-se da 1a Escola de Meninas da Freguesia da Candelária. Estranho, no entanto, que Antenor Nascentes tenha estudado com Amélia nesta escola da Rua da Quitanda no 33 (Almanak Laèmmert, 1891, p. 1617). Não encontrei documentação, ou sequer um indício, que Amélia tenha lecionado em alguma outra Escola de Meninos, além da 1a Escola de Meninos de São Salvador do Mundo de Guaratiba, em 1883, para a qual foi habilitada por concurso, pelo Decreto de 20 de novembro de 1883, “reconhecida a vantagem, já demonstrada pela experiência de outros países, de serem incumbidas senhoras da regência de Cadeiras do sexo masculino e por não haver disposição legal que a isso se opusesse" (IMPÉRIO, Relatório da Instrução Primária e Secundária, 1883, p. 49). A Escola de Meninos de Guaratiba não era no Centro, mas no subúrbio carioca. Suponho, então, que Antenor tenha sido aluno ouvinte na Escola de Meninas da Rua da Quitanda, o que era comum, ${ }^{8}$ hipótese reforçada pelo anúncio titulado "Escola da Candelária", no Diário do Commercio de 16 de dezembro de 1891, à p. 2, que inclui na relação de aprovados o menino Alberto Baptista (aprovado com distinção na 2a classe) e os garotos Francisco de Souza e José Luiz Martins (aprovados plenamente na 1a classe), todos podendo habilitar-se aos Exames promovidos pela

8 Pelos Relatórios da Instrução Primária e Secundária, observei que os quadros estatísticos apresentados em diversos anos são separados alunos matriculados e alunos ouvintes nas escolas públicas de ambos os sexos.
Instrução Pública, ou, hipótese também plausível, possa ter a memória de Antenor Nascentes se confundido, já que Amélia e João Francisco foram padrinhos de batismo de Olavo, filho de Antenor com D. Salomé Nascentes (A Época, 28 de junho de 1913, p. 4).

Seguindo pistas e sinalizando o "entrelaçamento de experiências dos sujeitos no tempo e no espaço" (GUSSI, 2008, s/p), verifiquei que a vida profissional de Amélia Fernandes da Costa $^{9}$ começou em 1873, quando assume a carreira docente na rede de escolas públicas primárias da Corte, como "adjunta sem vencimentos". Pelo Art. 3o do Regimento Interno das Escolas Públicas de 10 Grau, de 1855, naquele momento, ainda em vigor, todas as escolas públicas deveriam ter em seu quadro funcional um professor e um adjunto, o que nem sempre ocorria por falta de pessoal habilitado, fazendo com que o adjunto, muitas vezes, viesse a reger, sozinho, a única turma da escola em que fora lotado pela Instrução Pública. O adjunto, ou mestre-aluno, deveria ser "habilitado com suficientes conhecimentos das matérias que constituem a instrução primária" (RELATÓRIO DO IMPÉRIO, 1855, p. 8) e ter sido considerado, nos Exames Finais, propenso ao exercício do magistério. As atribuições do adjunto nomeado para as escolas públicas eram, dentre outras: apresentar-se decentemente vestido (Art. 1o, parágrafo 20); organizar, junto com o professor, o orçamento da escola e apresentá - lo ao Delegado respectivo (Art. 1o, parágrafo 5o); manter a escola em permanente asseio, varrendo a casa pelo menos uma vez ao dia, e lavando-a duas vezes a cada mês; manter as janelas sempre abertas ${ }^{10}$ (Art. 60), além de exi-

9 Casou-se, em 1888, com João Francisco da Costa Júnior, à época 3o secretário da Alfândega do porto do Rio de Janeiro. Comunicação de mudança de nome por casamento. (Cidade do Rio, 17 de janeiro de 1888, p. 1; A Instrucção publica: publicação hebdomadária de 1 de fevereiro de 1888, p. 23).

10 Preocupação higiênica necessária em uma cidade sujeita a epidemias cíclicas de varíola e peste bubônica. 
bir, trimestralmente, um mapa de alunos matriculados e sua frequência e, anualmente, o número de alunos e seus aproveitamentos nos Exames, notando, dentre os alunos, aqueles recomendados por "talento, aplicação e moralidade" (Art. 6으, parágrafo 60), para ocuparem o lugar de adjuntos o que, suponho, possa ter ocorrido no caso de Amélia, pois que ela, can- didatando-se ao cargo, foi nomeada, em 1873, como "adjunta interina sem vencimentos" para uma das 67 escolas públicas primárias existentes (RELATÓRIO DO IMPÉRIO, 1875, p. 344-352).

Para caracterizar a vida de Amélia, remontei esses "dados aparentemente negligenciáveis" (GINZBURG, 1989), registrando-os, interpretando-os e classificando-os:

Quadro 1 - Trajetória profissional de Amélia Fernandes da Costa (Amélia Augusta Fernandes) 1873- 1898

\begin{tabular}{|c|c|c|}
\hline Ano & Trajetória & Fonte \\
\hline 1873 & $\begin{array}{l}\text { Amélia Augusta Fernandes* nomeada } \\
\text { Adjunta sem Vencimentos em Ato de } 31 \text { de } \\
\text { julho de } 1873 .\end{array}$ & $\begin{array}{l}\text { RELATÓRIO DA INSTRUÇÃO PRIMÁRIA E SECUNDÁRIA, } \\
\text { IMPÉRIO, 1873, p. } 22 . \\
\text { A NAÇÃO: JORNAL POLÍTICO, COMERCIAL E LITERÁRIO } \\
\text { (RJ), } 4 \text { de agosto de } 1873, \text { p. } 2 \text {. }\end{array}$ \\
\hline 1874 & $\begin{array}{l}\text { Submetida a Exame Oral para Professor } \\
\text { Adjunto. }\end{array}$ & JORNAL DO COMMERCIO, 29 de abril de 1874, p. 7. \\
\hline 1875 & $\begin{array}{l}\text { Aviso } 4.066 \text { de } 30 \text { de junho de } 1875 \text { promove } \\
\text { como Adjunta no 3o ano de exercício. }\end{array}$ & $\begin{array}{l}\text { ALMANAK LAEMMĖRT, 1875, p. } 105 \\
\text { A REFORMA: ÓRGÃO DEMOCRÁTICO (RJ), } 10 \text { de julho de } \\
\text { 1875, p. } 2 .\end{array}$ \\
\hline \multirow[b]{2}{*}{1877} & $\begin{array}{l}\text { Qualificada para receber gratificação pelo seu } \\
\text { "triênio de habilitação terminado" (p. 106). }\end{array}$ & ALMANAK LAEMMÈRT, 1877, p. 106. \\
\hline & Promovida a Adjunta efetiva de 10 grau. & $\begin{array}{l}\text { RELATÓRIO DA REPARTIÇÃO DOS NEGÓCIOS DO IMPÉRIO, } \\
\text { 1877, p. } 68 \text {. Nos Atos de } 17 \text { e } 25 \text { de julho; } 2 \text { e } 25 \text { de } \\
\text { setembro e } 9 \text { de outubro de nomeação de “adjuntos } \\
\text { efetivos às escolas públicas de 1o Grau". }\end{array}$ \\
\hline \multirow{2}{*}{1879} & $\begin{array}{l}\text { Nomeada Adjunta de 1o Grau que Recebe } \\
\text { Gratificação. }\end{array}$ & ALMANAK LAEMMÈRT, 1879, p. 112. \\
\hline & $\begin{array}{l}\text { Lotada na 1a Escola de Meninas da Freguesia } \\
\text { de São Salvador do Mundo de Guaratiba. }\end{array}$ & GAZETA DA TARDE, 22 de novembro de 1883, p. 3. \\
\hline 1882 & $\begin{array}{l}\text { Designada pela Instrução Pública para } \\
\text { regência interina na 1á Escola de Meninas } \\
\text { da freguesia do Santíssimo Sacramento } \\
\text { por falecimento da professora Polycena de } \\
\text { Menezes Dias da Cruz Araujo. }\end{array}$ & $\begin{array}{l}\text { IMPÉRIO, RELATÓRIO DA INSTRUÇÃO PRIMÁRIA E } \\
\text { SECUNDÁRIA, 1882, p. } 57 .\end{array}$ \\
\hline \multirow[t]{2}{*}{1883} & $\begin{array}{l}\text { Habilitada, por concurso, como professora, para } \\
\text { reger turma na 1a Escola de Meninos de São } \\
\text { Salvador do Mundo de Guaratiba, começando } \\
\text { “imediatamente este exercício docente, antes } \\
\text { do término do período letivo" (p. 2). }\end{array}$ & $\begin{array}{l}\text { DECRETO de } 20 \text { de novembro de } 1883 \text { e } \\
\text { IMPÉRIO, Relatório da Instrução Primária e Secundária, } \\
1883 .\end{array}$ \\
\hline & $\begin{array}{l}\text { Nomeada para 1á Escola de Meninos da } \\
\text { Freguesia de São Salvador do Mundo de } \\
\text { Guaratiba. }\end{array}$ & $\begin{array}{l}\text { GAZETA DA TARDE, } 22 \text { de novembro de 1883, p. } 3 . \\
\text { JORNAL DO COMMERCIO, } 22 \text { de novembro de } 1883, \text { p. } 1 .\end{array}$ \\
\hline \multirow{3}{*}{1884} & $\begin{array}{l}\text { Designada, por ato do Inspetor Geral } \\
\text { da Instrução Pública, para assumir } \\
\text { interinamente a 1á Escola de Meninas } \\
\text { da Freguesia de Santo Antônio, por } \\
\text { impedimento da professora, vinda da 1ạ } \\
\text { Escola de Meninos de Guaratiba. }\end{array}$ & GAZETA DA TARDE, 22 de janeiro de 1884, p. 1. \\
\hline & $\begin{array}{l}\text { Solicita transferência da 1ạ Escola de } \\
\text { Meninos da Freguesia de Guaratiba para a 1a } \\
\text { Escola de Meninas de S. Cristóvão. }\end{array}$ & GAZETA DA TARDE, 29 de setembro de 1884, p. 1. \\
\hline & $\begin{array}{l}\text { Transferida, a pedido, da 1á Escola de } \\
\text { Meninos de Guaratiba para a 1á Escola de } \\
\text { Meninas de S. Cristóvão. }\end{array}$ & DIÁRIO DE BRAZIL, 30 de setembro de 1884, p. 2. \\
\hline
\end{tabular}




\begin{tabular}{|c|c|c|}
\hline \multirow{3}{*}{1885} & $\begin{array}{l}\text { Solicita transferência da Escola de Meninas } \\
\text { da Freguesia de S. Cristóvão para a 1á Escola } \\
\text { de Meninas da Candelária. }\end{array}$ & O PAIZ, 27 de abril de 1885, p. 1. \\
\hline & $\begin{array}{l}\text { Transferida, a pedido, da 1á Escola de } \\
\text { Meninas da Freguesia de S. Cristóvão para a } \\
\text { 1a Escola de Meninas da Candelária. }\end{array}$ & O PAIZ, 27 de abril de 1885, p. 1. \\
\hline & $\begin{array}{l}\text { Recebe } 4 \text { meses de licença médica com } \\
\text { ordenado. }\end{array}$ & NOVIDADES, 19 de março de 1887, p. 3. \\
\hline \multirow{3}{*}{1888} & $\begin{array}{l}\text { Amélia Fernandes da Costa* nomeada } \\
\text { Adjunta da } 1 \text { a Escola de Meninas da } \\
\text { Candelária. }\end{array}$ & JORNAL DO COMMERCIO, 10 de junho de 1888, p. 2. \\
\hline & $\begin{array}{l}\text { Exonerada pelo Art. } 20 \text { do Decreto } 8.985 \text { de } \\
11 \text { de agosto de } 1883 \text {, pelo Decreto de } 6 \text { de } \\
\text { junho de } 1888 \text {, do lugar de professora da } \\
\text { Escola pública de Meninas da Candelária. }\end{array}$ & JORNAL DO COMMERCIO, 13 de junho de 1888, p. 1. \\
\hline & $\begin{array}{l}\text { Nomeada adjunta efetiva às escolas } \\
\text { públicas de instrução primária do } \\
\text { Município da Corte, designada para reger } \\
\text { interinamente na 1á Escola de Meninas da } \\
\text { Freguesia da Candelária. }\end{array}$ & $\begin{array}{l}\text { JORNAL DO COMMERCIO, } 16 \text { de junho de } 1888 \text {, p. } 2 . \\
\text { GAZETA DA TARDE, } 16 \text { de junho de } 1888, \text { p. } 2 .\end{array}$ \\
\hline 1889 & $\begin{array}{l}\text { Nomeada para professora da 1a Escola de } \\
\text { Meninas da Freguezia da Candelária. }\end{array}$ & GAZETA DE NOTICIAS, 3 de maio de 1889, p. 1. \\
\hline \multirow[b]{2}{*}{1890} & $\begin{array}{l}\text { "Declarou-se de serventia vitalícia o } \\
\text { provimento da professora da Escola Pública } \\
\text { de Meninas da Candelária, Amélia Fernandes } \\
\text { da Costa, visto contar com mais de } 5 \text { anos } \\
\text { de efetivo exercício" (p. 1). }\end{array}$ & GAZETA DE NOTÍCIAS, 5 de fevereiro de 1890, p. 1. \\
\hline & $\begin{array}{l}\text { Designada pelo Ministério da Instrução } \\
\text { Pública, Correios e Telégrafos "para viajar a } \\
\text { países estrangeiros para visitar as escolas e } \\
\text { estudar a organização do ensino primário" } \\
\text { em viagem Comissionada à Itália, França } \\
\text { e Bélgica. "Partiu ante-hontem para a } \\
\text { Europa em comissão do Governo a distincta } \\
\text { professora pública D. Amélia Fernandes da } \\
\text { Costa. Seu embarque foi muito concorrido, } \\
\text { por discípulas suas e grande número de } \\
\text { famílias de nossa melhor sociedade" (p. 1). }\end{array}$ & $\begin{array}{l}\text { CIDADE DO RIO, } 16 \text { de outubro de 1890, p. } 1 . \\
\text { GAZETA DA TARDE, } 1 \text { de dezembro de 1890, p. } 1 .\end{array}$ \\
\hline 1891 & $\begin{array}{l}\text { "Devem chegar 2a feira, a bordo do vapor } \\
\text { Thines, os professores Luiz Augusto dos Reis } \\
\text { e D. Amélia Fernandes da Costa" (p. 2). }\end{array}$ & GAZETA DA TARDE, 20 de junho de 1891, p. 2. \\
\hline \multirow{3}{*}{1895} & $\begin{array}{l}\text { Visita ao Pedagogium com alunas e } \\
\text { professoras. "As allumnas offereceram } \\
\text { em nome da Escola um ramo de flores } \\
\text { ao Sr. Diretor do Pedagogium, a que S. Sa } \\
\text { agradeceu retribuindo com a oferta de } \\
\text { livrinhos cuja distribuição confiou à digna } \\
\text { professora" (p. 2). }\end{array}$ & CIDADE DO RIO, de 1 de dezembro de 1895, p. 2. \\
\hline & $\begin{array}{l}\text { Festa de "Distribuição de Prêmios às alunas } \\
\text { [aprovadas] da 2a Escola do } 3 \text { o distrito sob } \\
\text { o magistério da zelosa professora Amélia } \\
\text { Fernandes da Costa [...] Presente o Dr. Raul } \\
\text { Martins, Inspetor Escolar" (p. 2). }\end{array}$ & O PAIZ, 9 de setembro de 1895, p. 2 . \\
\hline & $\begin{array}{l}\text { Exposição, na vitrine da Papelaria } \\
\text { Ferdinando (à Rua do Ouvidor), de fotos } \\
\text { em homenagem a Amélia pelas alunas que } \\
\text { naquele ano terminaram seu curso na 4ạ } \\
\text { Escola Pública de Meninas da Candelária. }\end{array}$ & JORNAL DO BRAZIL, 11 de março de 1895, p. 2. \\
\hline
\end{tabular}




\begin{tabular}{|c|c|c|}
\hline \multirow{4}{*}{1896} & $\begin{array}{l}\text { Recebe gratificação adicional por ter } \\
\text { completado } 20 \text { anos de serviço no } \\
\text { magistério público. }\end{array}$ & CIDADE DO RIO, 9 DE MAIO DE 1896, p. 1. \\
\hline & $\begin{array}{l}\text { Visita, com alunas e professoras, o } \\
\text { Pedagogium, sendo recebida pelo Diretor } \\
\text { Menezes Vieira. }\end{array}$ & CIDADE DO RIO, 1 de dezembro de 1896, p. 2. \\
\hline & $\begin{array}{l}\text { Visita com alunas a Exposição Artística } \\
\text { comemorando a Entrada da Esquadra Legal. }\end{array}$ & JORNAL DO COMMERCIO, 13 de novembro de 1896, p. 6. \\
\hline & $\begin{array}{l}\text { Amélia recebe como adjuntas Mathilde } \\
\text { Montenegro, Maria Thomazia Monteiro e } \\
\text { Beatriz Sespes. }\end{array}$ & JORNAL DO BRAZIL, 5 de setembro de 1896, p. 2. \\
\hline 1897 & $\begin{array}{l}\text { Encaminha ao jornal o livro "Lições de } \\
\text { Cousas", de sua autoria, "de acordo com os } \\
\text { preceitos de pedagogia moderna, aprovado } \\
\text { e adotado nas escolas públicas por } \\
\text { indicação do Conselho de Instrução" (p. 1). }\end{array}$ & GAZETA DA TARDE, 23 de novembro de 1897, p. 1. \\
\hline \multirow[b]{3}{*}{1898} & $\begin{array}{l}\text { Jubilada pelo Decreto no } 52 \text { de } 9 \text { de abril de } \\
1897 \text { como professora catedrática. }\end{array}$ & $\begin{array}{l}\text { GAZETA DA TARDE, } 3 \text { de janeiro de } 1898 . \\
\text { O PAIZ, } 4 \text { de janeiro de } 1898, \text { p. } 1 .\end{array}$ \\
\hline & $\begin{array}{l}\text { Substituída do Conselho Superior de } \\
\text { Instrução por sua jubilação. }\end{array}$ & GAZETA DE NOTÍCIAS, 12 de março de 1898, p. 1. \\
\hline & $\begin{array}{l}\text { Louvor da Diretoria Geral de Instrução } \\
\text { Municipal em Seção de } 14 \text { de março de } \\
1898 \text { "pelo modo correto com que sempre } \\
\text { desempenhou as funções do cargo de } \\
\text { membro do Conselho Superior de Instrução" } \\
\text { (p. 4). }\end{array}$ & JORNAL DO COMMERCIO, 22 de março de 1898, p. 4. \\
\hline
\end{tabular}

Fonte: Elaborado pela autora, com base nas fontes mencionadas no quadro. *Alteração do nome por casamento.

Analisando o quadro, verifico que a vida profissional de Amélia foi pautada por suas constantes, e sempre muito rápidas, transferências de uma para outra escola, o que me levou a questionar se haveria razão pessoal da professora, intermediado por seu relacionamento na Diretoria de Instrução,11 para trocar, a pedido, na maioria das vezes, de uma escola para outra, em curtíssimos espaços temporais, iniciando sua docência em escolas suburbanas até chegar à Escola da Candelária, à rua da Quitanda, citada por Antenor Nascentes. Pude saber, ainda pelos jornais, que Amélia mantinha em sua rede de sociabilidade integrantes da Instrução Pública em vários níveis hierárquicos, inclusive Benja-

11 Foi madrinha de casamento do 1o Oficial da Diretoria da Instrução Pública, Major Mário Pinto Barreto com Antonieta Barroso de Araujo, na Igreja São João Batista, em Niterói (Cidade do Rio, 18 de maio de 1895, p. 2); compareceu à missa fúnebre do filho de Benjamin Franklin Ramiz Galvão (Gazeta de Notícias, 21 de março de 1893, p. 1).

\section{min Franklin Ramiz Galvão, Barão de Ramiz ${ }^{12}$}

12 Filho de João Galvão e de D. Maria Joana Ramiz Galvão, Benjamin Franklin Ramiz Galvão nasceu em 16/06/1846 em Rio Pardo, Rio Grande do Sul, mudando-se para o Rio de Janeiro, então capital do Império, aos 6 anos de idade. Em 1861, formou-se bacharel no Colégio Pedro II. Graduou-se na Faculdade de Medicina, em 1868. Atuou como médico na Guerra do Paraguai e como cirurgião no Hospital Militar da Ponta da Armação. Passou a dedicar-se ao magistério. Trabalhou no Colégio Pedro II (lecionava Grego, Retórica, Poética e Literatura brasileira); na Escola de Medicina do Rio de Janeiro (lecionou Química orgânica, Zoologia e Botânica). Recebeu o título de Barão de Ramiz, por decreto de 18 de junho de 1888. Assumiu a direção da atual Biblioteca Nacional. Ao longo dos doze anos de sua gestão, destacam-se a organização da exposição camoniana de 1880 , e as publicações dos Anais da Biblioteca Nacional e do Catálogo da Exposição de História do Brasil. Ocupou ainda os cargos de diretor do Asilo Gonçalves de Araújo, entre 1899 e 1931; primeiro reitor da Universidade do Brasil; e, por duas vezes, diretor-geral da Instrução Pública do Distrito Federal, de 15/08/1893 a 11/12/1893, e de 23/04/1912 a 26/03/1915. Em 12 de abril de 1928, aos 82 anos, foi eleito para ocupar a cadeira 32 da Academia Brasileira de Letras, presidindo-a em 1934. Foi sócio benemérito e orador perpétuo do Instituto Histórico e Geográfico Brasileiro; dirigiu o Almanaque Garnier. Escreveu "O púlpito no Brasil" e "Vocabulário Etimológico, Ortográfico e Prosódico das Palavras Portuguesas Derivadas da Língua Grega" (1909). Faleceu em 09/03/1938, aos 92 anos, no Rio de Janeiro. VILELA, Amanda. RAMIZ 
(diretor-geral da Instrução Pública do Distrito Federal de 15/08/1893 a 11/12/1893, e de 23/04/1912 a 26/03/1915).

Na Escola da Candelária, parece-me, concretiza-se seu sonho de professora, $1^{13}$ o que explicaria não ter mais solicitado, ou ser designada, para outra escola, cumprindo o prazo de cinco anos, estabelecido pela legislação em vigor naquele momento, para que se tornasse vitalícia naquela unidade escolar. Outro vestígio desta preferência de Amélia pela Escola da Candelária foi sua iniciativa, tão logo assumiu esta escola, de trocar, às suas expensas, o mobiliário escolar, no que foi ressarcida, meses depois, pela Instrução Pública (Diário Portuguez, 29 de agosto de 1885, p. 2). Este indício mostrou-me, também, que Amélia pertencia a uma família de posses, antes ${ }^{14}$ e depois do casamento com João Francisco da Costa Júnior, ${ }^{15}$ pois a professora teve condições de equipar a escola em que trabalhava com móveis mais modernos, adequados às novas metodologias de ensino, ${ }^{16}$ além de presentear às alunas aprovadas nos anos letivos de 1891 (Diário de Notícias, 16 de dezembro de 1891, p. 2), 1895 e 1896, da Escola da Candelária, com joias e poupança, o que contou com longa publicização na imprensa.

GALVÃO, Benjamin Franklin Diretor Geral de Instrução Pública Municipal. Disponivel em: <http://expagcrj. rio.rj.gov.br/ramiz-galvao-benjamin-franklin/>. Acesso em: 8 nov. 2018.

13 A escola situava-se na mesma freguesia onde trabalhava seu pai, seu marido e seu sogro, todos ligados à Alfandega, direta ou indiretamente.

140 pai de Amélia era rico comerciante, importador de secos e molhados na praça da Corte (Correio Mercantil e Instructivo, Político, Universal de 1 o de janeiro de 1862, p. 1), e oficial (10 Tenente) de Marinha reformado (Decreto de 25 de outubro de 1866).

150 pai de João Francisco da Costa Júnior era rico comerciante no Rio de Janeiro possuindo vapor de passageiros, e gêneros, incluindo transporte de escravos.

16 Ver: SANTOS, Heloisa Helena Meirelles dos.; MIGNOT, Ana Chrystina Venancio. Com a palavra, as carteiras escolares. In: SILVA, Vera Lúcia Gaspar da.; SOUZA, Gisele de.; CASTRO, César Augusto de. Cultura Material Escolar em Perspectiva Histórica: escritas e possibilidades. Vitória: EDUFES, 2018. p. 293-310.
A posição social de Amélia também foi marcada pela imprensa, em momentos distintos: convite para a participação de Amélia na Comissão das Festas da Abolição, divulgada pelo Diário de Notícias de 13 de maio de 1894, p. 1; $;{ }^{17}$ a forma como a Gazeta de Tarde de 1 o de novembro de 1890, na primeira página, publica seu embarque assistido por "grande número de famílias de nossa melhor sociedade"; noticia suas visitas, com alunas, ao Pedagogium e à Exposição Artística comemorativa da Entrada da Armada Legal ${ }^{18}$ no porto do Rio de Janeiro (Jornal do Commercio, 13 de novembro de 1896, p. 6), provavelmente por ter sido a Escola da Candelária uma das edificações atingidas por disparos durante a Revolta da Armada, em 1893 (O Tempo, 21 de novembro de 1893, p. 1).

0 quadro 2, a seguir, mostra que Amélia, ainda Amélia Augusta Fernandes, solteira, foi uma das primeiras alunas matriculadas na Escola Normal da Corte, em 5 de abril de 1880. A Escola Normal da Corte ${ }^{19}$ foi criada pelo Decreto 7.684 de 6 de março de 1880 que, de conformidade com o Art. 9, do Decreto 7.247 de 19 de abril de 1879, instituiu, no município da Corte, uma escola para a formação de professores e professoras da instrução primária. ${ }^{20}$

17 Também faziam parte da Comissão: Domingos Lisboa, Adelina Vieira, Antônio José Teixeira da Cunha e Aureliano de Andrade.

18 Episódio da Revolta da Armada (movimento de rebelião por divergências políticas, ocorrido em 1893, e liderado por algumas unidades da Armada contra o governo do presidente Floriano Peixoto). Ver: RIBEIRO, Atanagildo Barata. Sonho no cárcere: dramas da revolução de 1893 no Brazil. Rio de Janeiro: Casa Mont'Alverne, 1895.

19 Houve uma 1á Escola Normal da Corte, criada em 1874, para rapazes e moças que, por extinção da verba alocada para sua criação e funcionamento não chegou a funcionar.

20 Ver: MEIRELLES, Heloisa Helena. Estudando a Escola Normal da Corte. Disponivel em: <http://cemiiserj. blogspot.com/2008/07/estudando-escola-normal-dacorte.html>. Acesso em: 30 jul. 2008. 
Quadro 2 - Amélia Fernandes da Costa Trajetória Acadêmica na Escola Normal da Corte (1880-1889)

\begin{tabular}{|c|c|c|}
\hline Ano & Trajetória & Fonte \\
\hline 1880 & $\begin{array}{l}\text { Matricula-se na Escola Normal da Corte como Amélia } \\
\text { Augusta Fernandes, solteira. }\end{array}$ & LIVRO DA PORTA \\
\hline 1883 & $\begin{array}{l}\text { Chamada pela Escola Normal da Corte para fazer o } \\
\text { Exame de Caligrafia e Desenho Linear. }\end{array}$ & $\begin{array}{l}\text { JORNAL DO COMMERCIO, dias } 26 \text { e } 27 \text { de } \\
\text { junho de } 1883, \text { p. } 1 .\end{array}$ \\
\hline 1887 & $\begin{array}{l}\text { Aprovada na Escola Normal da Corte no Exame de } \\
\text { português relativo à } 2 \text { a série. }\end{array}$ & O PAIZ, 30 de dezembro de 1887, p. 2. \\
\hline 1888 & $\begin{array}{l}\text { Amélia Fernandes da Costa é chamada pela Escola } \\
\text { Normal da Corte para prova oral de Pedagogia às } 17 \mathrm{~h} \\
\text { de } 17 \text { de fevereiro de } 1888 \text { com a presença de S. M. o } \\
\text { Imperador. }\end{array}$ & CIDADE DO RIO, 17 de fevereiro de 1888. \\
\hline \multirow{2}{*}{1889} & $\begin{array}{l}\text { Aprovação "com distinção" na Cadeira de Corografia e } \\
\text { História do Brasil em exame da Escola Normal da Corte } \\
\text { realizado no período de } 14 \text { a } 16 \text { de janeiro de } 1889 \text {. }\end{array}$ & $\begin{array}{l}\text { JORNAL DO COMMERCIO, } 22 \text { de janeiro de } \\
1889, \text { p. } 2 .\end{array}$ \\
\hline & $\begin{array}{l}\text { Aprovada "plenamente" em Álgebra, Geometria e } \\
\text { Trigonometria em Exame da Escola Normal da Corte } \\
\text { realizado dias } 30 \text { e } 31 \text { de janeiro de } 1889 .\end{array}$ & $\begin{array}{l}\text { GAZETA DE NOTÍCIAS, } 5 \text { de fevereiro de } 1889 \text {, } \\
\text { p. } 1 .\end{array}$ \\
\hline
\end{tabular}

Fonte: Elaborado pela autora, com base nas fontes mencionadas no quadro.

Comparando os quadros 1 e 2 , verifico que, ao matricular-se, Amélia já contava sete anos de exercício, como Adjunta de 1o Grau, nas escolas públicas da Corte e trabalhava na 1a Escola de Meninas da Freguesia de São Salvador do Mundo de Guaratiba. Face ao seu trabalho docente, bem longe do centro, em época de poucos e precários meios de locomoção, e pelo Regulamento Escolar que permitia ao aluno sua matrícula por Cadeira, suponho que não tivesse podido fazer um curso normal contínuo, como usualmente se faz. À época da matrícula de Amélia, a Escola Normal da Corte, ${ }^{21}$ iniciando seu funcionamento, estava sediada na Escola Politécnica, ${ }^{22}$ con-

21 A Escola Normal da Corte foi inaugurada em dependências do Colégio de Pedro II, com a presença do imperador, mas ali não pôde ficar pelo grande número de alunos matriculados. Foi transferida para a Escola Politécnica, onde ficou até 1888 , quando se mudou para a extinta escola de Sant'Anna, na Praça da Aclamação, esquina de rua S. Pedro. (SANTOS, 2011)

22 Sobre a Escola Normal da Corte ver: SANTOS, Heloisa Helena Meirelles dos. Congregação da Escola Normal: da legitimidade outorgada à legitimidade (re)conquistada (1880-1910). 2011. 212 f. Dissertação (Mestrado em Educação) - Programa de Pós-Graduação em Educação (PROPEd), Universidade do Estado do Rio de Janeiro (UERJ), Rio de Janeiro, 2011. Disponivel em: <http:// heloisahmeirelles.blogspot.com/p/congregacao-da-escola-normal-da.html>. Acesso em: 12 set. 2018. tando com 282 alunos matriculados, sendo 105 do sexo masculino e 177 do sexo feminino (IMPÉRIO, Relatório da Instrução Pública sobre a Escola Normal da Corte, de 1888-A, p. 56; Livro da Porta, 1880). A partir do Regulamento da Escola Normal da Corte, de 1881, elaborado pela Congregação dos seus professores face à experiência educacional que traziam (SANTOS, 2011), Amélia Augusta e seus colegas passaram a obedecer ao seguinte currículo: Português, Francês, Educação Religiosa, Matemáticas elementares, Corografia e História do Brasil, Cosmografia, Geografia e História Geral, Elementos de Mecânica e Astronomia, Ciências Físicas, Ciências Biológicas, Lógica, Direito Natural e Público, Pedagogia e Metodologia e Noções de Agricultura. Eram Cadeiras facultativas pelo Regulamento as Cadeiras de Francês e Educação Religiosa, e aquelas ministradas por Mestres, como Ginástica, Trabalhos de Agulha etc. (SANTOS, 2011). Interessante mencionar que, ao concluir o curso normal, Amélia recebeu o diploma da Escola Normal da Capital Federal, designação da Escola Normal da Corte com o advento do novo regime político brasileiro, a república. 
Porque "o historiador é comparável ao médico [...] o conhecimento histórico é indireto, indiciário, conjetural" (GINZBURG, 1989, p. 156157), observei que os últimos Exames na Escola Normal da Corte de Amélia foram feitos quase consecutivamente, depois de longo espaço de tempo sem fazê-los, quando já existiam rumores na cidade de uma reforma educacional, o que possibilitou que ascendesse, pela formação, de adjunta a professora. Nesta promoção funcional, também notei uma provável indicação que, suponho, sua rede de sociabilidade (SIRINELLI, 1996) ${ }^{23}$ pode ter proporcionado, já que a professora estava há muitos anos como adjunta sem ser alçada professora. Poderia, questionei-me, Amélia fazer esta viagem comissionada como adjunta, se os demais indicados eram, todos, professores?

Tanto "para o filósofo natural, como para o filólogo, o texto é uma entidade profunda invisivel, a ser reconstruída para além dos dados sensiveis" (GINZBURG, 1989, p. 158), verifiquei que Amélia, não tendo comprovado sua habilitação na Escola Normal junto à Instrução Pública, em 1888, quando muda a legislação de ensino por troca do Gabinete do Império, ${ }^{24}$ foi exonerada do cargo de professora primária pelo Decreto de 6 de junho de 1888, art. 20. Ao comprovar, a seguir, em 1889, sua matrícula e provas já realizadas na Escola Normal da Corte, de que havia ficado dependente, Amélia é

23 "As estruturas de sociabilidade permitem, não só um observatório, como um lugar para analisar o movimento de ideias" (SIRINELLI, 1996, p. 249). Como Amélia pertencia à elite econômica e social dos grandes comerciantes importadores, suponho que os salões, saraus e outros espaços sociais da elite carioca, inclusive os templos religiosos, tenham sido o lugar de contato da rede que "[se organiza] a partir de uma sensibilidade ideológica ou cultural comum e de afinidades, que alimentam o desejo e o gosto de conviver" (SIRINELLI, 1996, p. 246).

24 O Gabinete Conservador presidido por João Alfredo Correia de Oliveira é substituído pelo Gabinete Liberal de Afonso Celso de Assis Figueiredo, Visconde de Ouro Preto. Ver: FERRAZ, Paula Ribeiro. 0 Império em tempos de conciliação: atores, ideias e discursos (1848-1857). Belo Horizonte: Editora Fino Traço, 2016. renomeada professora pública primária e relotada na 1a Escola de Meninas da Freguesia da Candelária, onde fica até jubilar-se, em 1898, como "professora catedrática" (Jornal do Brasil, 8 de abril de 1931, p. 8).

Seguindo o método indiciário, permito-me atentar, usando o "olho clínico - olho do conhecedor - algo mais que uma simples coincidência" (GINZBURG, 1989, p. 159) para saber, ainda, da influência da rede de sociabilidade de Amélia: em 1891, a diretora da Escola da Candelária recebe como sua professora adjunta Elvira Baptista de Mattos, que a substitui quando de sua viagem comissionada à Europa e, em 1896, recebe mais três adjuntas, Mathilde Montenegro, Maria Thomazia Monteiro e Beatriz Sespes. Percebo que a pequena Escola de Meninas da Candelária, à chegada de Amélia, tinha, segundo o Relatório da Instrução Pública Primária e Secundária de 1889, quatro alunas apenas, com uma só matrícula em 1889 (três ouvintes). Ora, as escolas com poucos alunos foram extintas para a economia dos cofres públicos, exceto a Escola de Meninas da Freguesia da Candelária, que se manteve com uma só aluna matriculada! Penso na rede de sociabilidade da professora que, suponho, a legitimava, também, na permanência desta escola sem alunas.

Comparando a pesquisa, e os dados descobertos, como "os fios de um tapete [cuja] coerência do desenho é verificável percorrendo o tapete com os olhos em várias direções" (GINZBURG, 1989, p. 170), analiso o fato de Amélia, como responsável pela Escola da Candelária, em 1895 e 1896, ter levado suas alunas a conhecerem o Pedagogium, tendo a comitiva visitante sido recebida pelo seu diretor, o professor Joaquim José de Menezes Vieira (18511897), o que não era usual. Interrogando-me sobre tamanha deferência a uma visita escolar, verifiquei, também pela imprensa, que Menezes Vieira e o pai de Amélia, provavelmente 
se conheciam, já que ambos estiveram juntos inúmeras vezes como jurados nas mesmas sessões do Tribunal de Justiça da Corte (Jornal do Commercio, 4 de maio de 1880 , p. 3). Nas visitas à instituição, o diretor guiou o grupo por todas as dependências, explicando o funcionamento do Pedagogium. A primeira visita de Amélia foi amplamente publicizada pelo jornal Cidade do Rio de 10 de dezembro de 1895, à p. 2, o que me forneceu indícios para supor que a professora tivesse sua legitimidade reconhecida pela imprensa, pois que o Pedagogium recebia muitas visitas de professores, alunos e turmas, que não eram objeto de menção nos jornais, nem recebidas e/ou guiadas pelo diretor da instituição.

Em 1896, já com 20 anos de efetivo exercício, passou Amélia a receber gratificação adicional relativa ao tempo de docência no magistério público primário (Cidade do Rio, 9 de maio de 1896, p. 1), jubilando-se dois anos após como professora catedrática.

\section{Indícios da rede de sociabilidade: o capital social ${ }^{25}$ de Amélia}

Cada sociedade observa a necessidade de distinguir os seus componentes; mas os modos de enfrentar essa necessidade variam conforme os tempos e lugares. Existe, antes de mais nada, o nome; mas, quanto mais a sociedade é comple$\mathrm{xa}$, tanto mais o nome parece insuficiente para circunscrever inequivocadamente a identidade de um indivíduo. (GINZBURG, 1989, p 171-172)

Como desvelar a rede de sociabilidade de Amélia, seu "capital social"26 (BOURDIEU, 2007),

25 Expressão usada no sentido de Bourdieu "de [ser] um conjunto de recursos atuais ou potenciais que estão ligados à posse de uma rede durável de relações mais ou menos institucionalizadas de interconhecimento e de inter-reconhecimento ou, em outros termos, à vinculação a um grupo, como conjunto de agentes que não somente são dotados de propriedades comuns passiveis de serem pelo observador, pelos outros ou por eles mesmos) mas também são unidos a ligações permanentes e úteis". (BOURDIEU, 2007, p. 67)

26 "A noção de capital social emergiu como a única e os benefícios obtidos em razão da sua participação e na construção de sociabilidades? Apenas procurando-a pelo nome? Estava, neste momento da investigação, como Ginzburg (1989), "[disposta] a descartar a priori a eventualidade de que tal analogia implicasse uma relação histórica a ser inteiramente reconstruída" (1989, p. 11), por isso, voltei à pesquisa nos jornais, usando como entrada de pesquisa a Escola da Candelária e não mais os nomes da personagem objeto de pesquisa (antes e depois do casamento). Ampla matéria do Diário de Notícias, publicada em 12 de dezembro de 1888 , revelou-me que "realizou-se [às seis horas da tarde] com a maior solemnidade a festa de distribuição de prêmios de aplicação das alumnas d'esta escola [1] Escola de Meninas da Freguesia da Candelária], habilmente dirigida pela distincta professora D. Amélia Fernandes Costa" (p. 2). ${ }^{27}$ Divulga, também, o periódico que foram distribuídos no evento joias (pulseiras de ouro, pulseiras de prata, alfinetes de ouro, alfinetes de prata), cadernetas de poupança (de 25 mil réis) e medalhas "oferecidos pela respectiva professora" (Diário de Notícias, 12 de dezembro de 1888, p. 2), além de estojo de costura, oferecido por D. Maria de Azevedo e de um livro dourado oferecido pelo prof. Paulino Martins Pacheco (professor de Desenho da Escola Normal da Corte). Comenta também o jornal que, após a festa na escola, foi oferecido por Amélia um jantar a alunos e convidados durante o qual foram ofertados outros brindes, aos alunos, dentre os quais os

maneira de conceber o princípio dos efeitos sociais [vistos] no nível dos agentes singulares - onde a investigação estatística [... se encontra - não pode ser ignorado porque são tomados como um]conjunto de propriedades individuais possuídas por um agente determinado [expressos no] grau [mobilizado] por procuração [do] capital de um grupo (família, ex-alunos de escolas de elite, seleto clube, nobreza, etc.) mais ou menos constituído como tal e mais ou menos capaz de [produzir e fomentar] capital" (BOURDIEU, 1980, p. 2)

27 Obedecida a grafia da fonte. 
da Sra. Senador Correia,, ${ }^{28}$ Dra. Bittencourt, Oliva Maia e Dr. Joaquim do Amaral.

o jantar, teve o seguinte menu divulgado pelo impresso:

\section{Diner des envités ${ }^{29}$}

Creme de volaille (potage); Poisson fin sauce tartare. Petits patê de poulets; Filets du boeauf a la jardinière; Dinde truffè; Jambon de York; Mayonnese d'homards. Desserts: Salade de fruits; Charlotte russe; Pudding de gabinete; fruis divers. Vins: Xerès, Madère, Poto fin, Bordeaux, Bourgogne, e Champagene. Liqueurs.

\section{Diner des élèves $^{30}$}

Potage à la Reine; Files de poisson; Ecrevises fareies; Croquettes de pore. Desserts: Salade de fruits; Charlotte russe; Pudding de gabinete; Fruits divers e biscuits. Vins: Xerès, Madère, Bourgogne, e Champagene. Liqueurs.

Foram convidados de Amélia e seu marido João Francisco, como citados pelo jornal, de fora do círculo escolar, e parte de sua rede de relações, presentes às comemorações da Escola da Candelária: as Marquesas de Funchal, a Condessa de Alcoçovas, a Condessa de Sabugosa, D. Rita de Barros Gomes; o General Sá Carneiro, o Coronel Antônio de Campos, o General Dias, o Vice-almirante Andrade Pinto, o General Teixeira Rabello, o Coronel Vito Moreira, os Capitães Fernando de Serpa e Teixeira de Carvalho; o presidente do Conselho de Ministros da Justiça e dos Estrangeiros, Visconde de Asseca, o Conde das Alcoçovas, o conde de S. Mamede, Duval Telles e D. Maria de Azevedo. De sua rede educacional lá estavam, também, o Professor Paulino Pacheco e o redator do jornal italiano Il Bersaglière (Diário do Commer-

28 Esposa de Leôncio Correia (1865- 1950), que foi político (deputado 1897-1899), escritor e, também, Diretor do Ginásio Fluminense em Petrópolis (RJ), Diretor do Ginásio Nacional e Diretor da Instrução Pública na capital Federal, Professor de História da Escola Normal e diretor da Imprensa Nacional e do Diário Oficial. Disponivel em: <https://cpdoc.fgv.br/sites/default/files/ verbetes/primeira-republica/CORREIA,\%20Le\%C3\%B4ncio.pdf>. Acesso em: 12 ago. 2018.

29 Jantar dos convidados.

30 Jantar dos alunos. cio, de 16 de dezembro de 1891, p. 2), dentre os demais não citados nominalmente, que degustaram o outro cardápio, também publicizado:

Consommé à la Royale; Quenelles à la Chevalière; Poisson guarni sauce hollandaise; Filet de boeuf à la Richelieu; Côtelettes de cailles à la Kisseleff, Suprês de volaille aux truffes; Pain-de-lièvres à la Princesasse; Salase russe; Dindonneau rotis au cresson; Petits pois à l'anglaise; Gâteau Cussy à la crême; Brèsilien au cognac; Glace aux fruits. (Diário de Notícias, 12 de dezembro de 1888 , p. 2)

O jantar oferecido, tanto para convidados de Amélia e João Francisco, de sua rede social e educacional, quanto para os alunos e seus convidados, todos foram divulgados com cardápio em francês. 0 idioma dos cardápios era natural em momento de efervescência de Belle Époque ${ }^{31}$ no Rio de Janeiro, onde usar o idioma era símbolo de civilização e modernidade da elite, marcando, na publicização feita pela imprensa, o pertencimento dos anfitriões à "boa sociedade" da época.

A rede de sociabilidade de Amélia, exposta na reportagem, era composta por altas personalidades do Império, ainda que já se estivesse, havia pouquíssimo tempo, na república, mas incluía, também, integrantes de patentes superiores da Armada e do Exército e da sociedade carioca, do Império e da República, além de correspondente da imprensa, que aparecem para mim como marcas do relacionamento pessoal do casal, e que podem, provavelmente como indícios, explicar a concessão das inúmeras remoções de escola, da manutenção da escola que Amélia desejava, como também a escolha de Amélia, dentre outras professoras da rede de escolas públicas da capital da república, para integrar a primeira comissão de docentes que viajou à Europa, no novo regime.

31 Para o assunto consultar: VELLOSO, Mônica Pimenta. As tradições populares na belle époque carioca. Rio de Janeiro: FUNARTE, 1988. 
A festa de entrega de prêmios, de 1895, também divulgada pelo periódico $O$ Paiz de 9 de setembro de 1895, à p. 3 , descortinou-me a rede de sociabilidade de Amélia, e seu lugar social, ao mencionar que a aluna Eliza de Sá recebeu, como presente da professora Amélia, um "rico colar de ouro entregue [à discente] pelo Diretor da Instrução".

Outros indícios da rede de sociabilidade de Amélia, que os jornais possibilitaram conhecer, foram: seu comparecimento ao enterro de Benjamin Galvão, filho do Dr. Ramiz Galvão, onde aparece nominalmente citada, dentre as personalidades presentes, compostas por Lentes de várias instituições de ensino, Senadores, Professores e Médicos, que enviaram coroas de flores naturais como homenagem póstuma ao falecido (Gazeta de Notícias, 21 de março de 1893, p. 1); seu embarque, no porto do Rio de Janeiro, para a Europa, pela Gazeta da Tarde, que a incluía entre a "a nossa melhor sociedade", e a descrição jornalística de suas visitas ao Pedagogium, sempre recebida pelo Diretor da instituição.

\section{Família de Amélia}

Tentando distinguir [...] no momento da descrição, um nariz giboso-arcado de um nariz arcado-giboso [...]" (GINZBURG, 1989, p. 174), verifiquei, pelos impressos jornalísticos, que Amélia Augusta Fernandes, carioca, nascida em 18 de dezembro, ${ }^{32}$ era filha de Luiza Angélica da Cunha Fernandes (nascida em 1822 e falecida em 1855, de tuberculose pulmonar) ${ }^{33}$ e Adriano Manoel Fernandes, ambos brasileiros. A professora teve muitos irmãos: Maria Amélia Fernandes, Hermínia Amélia Fernandes, Luiza An-

32 Consegui saber apenas seu aniversário pela coluna "Felicitações" do jornal O Paiz de 18 de dezembro de 1894, p. 3. e da coluna "Parabéns" de O Tempo de 18 de dezembro de 1893, p. 2 . Sua ficha de matricula, no Centro de Memória do ISERJ, deteriorada pelo tempo e falta de manutenção, não pôde ser aberta.

33 o Diário do Rio de Janeiro, 13 de outubro de 1855, p. 2 informa que morreu aos 33 anos. gélica Fernandes, Corina Clarinda Fernandes, Adolpho Manoel Fernandes, Pedro Alberto Fernandes e Adolpho Manoel Fernandes (O Paiz, de 29 de janeiro de 1894, p. 3). Seu pai, Adriano Manoel Fernandes, era filho de D. Umbelina Luiza Fernandes e de Manoel Antônio Fernandes (Correio Mercantil e Instructivo, Político, Universal, de 10 de julho de 1862, p. 1). Foi aluno do Colégio do Barão de Tautphoeus (Correio Mercantil e Instructivo, Político, Universal, de 9 de novembro de 1857, p. 1), dirigido pelo renomado professor Joseph Herman ${ }^{34}$ onde se preparou para fazer o concurso da Escola de Marinha. Neste educandário, foi logo Adriano Manoel promovido a Guarda-Marinha (Correio Mercantil e Instructivo, Político, Universal, de 30 de julho de 1860, p. 1) e, ao longo do tempo, chega ao oficialato. Pediu Adriano Manoel Fernandes reforma, já como 1o tenente (Decretos de 6 e 10 de julho de 1867), para dedicarse ao comércio como negociante (importador de secos molhados) cadastrado da Praça da Corte (Correio Mercantil e Instructivo, Político, Universal 27 de maio de 1863, p. 3). ${ }^{35}$ Como rico comerciante da Corte, Adriano estabeleceu-se à Rua de São Pedro, no 7 (Almanak Laèmmert Administrativo, Mercantil e Industrial, 1860, p. 542), Foi ele, também, acionista da empresa responsável pela abertura, alargamento e nova edificação na Rua do Carmo (Jornal do Commercio, 25 de abril de 1855, p. 2); Diretor da Biblioteca Fluminense (Correio Mercantil e Instructivo, Político, Universal de 14 de agosto de 1865, p. 3), e fazia parte, como Secretário, da Irmandade de São José (Correio Mercantil e Instructivo, Político, Universal, abril de 1863, p. 3). ${ }^{36}$ Integrou, também, Adriano Manoel a Co-

34 Conta Soares (2018, p. 328) que o Barão "abriu colégios em Friburgo e no Rio de Janeiro, e nunca fechou a porta a quem carecesse instruir-se. Quem podia pagar pagava; quem não podia ficava de graça".

35 Decretada falência de seus negócios em 1870. Por pagamento a todos os seus credores, foi reabilitado em 1872. (Diário do Rio de Janeiro, 20 de março de 1872, p. 2)

36 O dia não é legível na 1a página, único lugar do periódico a informar a data da edição. 
missão Central, eleita pelos portugueses, para prover os Asilos da Infância Desvalida de Portugal (Correio Mercantil e Instructivo, Político, Universal, 28 de agosto de 1862, p. 2). Foi, ain$\mathrm{da}$, conselheiro da Sociedade União e Beneficência; Secretário da Irmandade do Patriarca S. José (Almanak Laèmmert Administrativo, Mercantil e Industrial, 1885, p. 376) ${ }^{37}$ e Mesário da Irmandade do Divino Espírito Santo da Lapa do Desterro (Almanak Laèmmert Administrativo, Mercantil e Industrial, 1863, p. 380). Pela profissão e muitas atividades de seu pai, percebo que Amélia teve vida de posses antes de seu casamento, em 1888, com João Francisco da Costa Júnior que também vinha de família de posses. ${ }^{38}$

O pai de João Francisco, marido de Amélia, o português João Francisco da Costa, iniciou sua vida profissional como belchior (comerciante de objetos usados ${ }^{39}$ ), quando comprou a escuna ${ }^{40}$ Benevente, a primeira de outras (ele compra posteriormente as sumacas ${ }^{41}$ Macahé,

37 Esta Sociedade, criada em 7 de março de 1852, tinha intuito beneficente, socorrendo seus sócios com pensões às viúvas, tratamentos médicos, missas etc. Em 1864, o capital social da instituição era de 98 mil réis, de valor nominal de 1.000 réis, o que restringia sua associação somente aos mais abastados. (Almanak Laèmmert Administrativo, Mercantil e Industrial, 1865, p. 387)

38 Para saber mais sobre comerciantes na Corte ver: MARSON, Izabel Andrade; OLIVEIRA, Cecília Helena de Salles. (Orgs.). Monarquia, liberalismo e negócios no Brasil: 1780-1860. São Paulo: Edusp, 2013.

39 Almanak Lèmmert, Administrativo, Mercantil e Industrial, de 1893, p. 589.

40 Uma escuna é um tipo de veleiro caracterizado por usar velas de popa a proa em dois ou mais mastros. O que as distingue é o fato do mastro de ré, ou mezena, ser maior e mais alto que os demais. "No ano de 1835, as apreensões aumentaram: bergantim 'Amizade Feliz', escuna 'Angélica', pataxo 'Continente', bergantim 'Aventura', sumaca. 'Novo Destino', brigue 'Orion' e sumaca 'Vencedora'. Em 1837: escuna 'Flor de Loanda' e pataxo 'César'. Em 1838: pataxos 'César' e 'Especulador', brigues 'Brilhante', 'Diligente' e 'Feliz', bergantim 'Carolina'. Em 1839: escuna 'Carolina', pataxo 'Especulador', brigues 'Ganges', 'Leão', ‘Pompeo' e ‘D. João de Castro', barca 'Maria Carlota' [...]”. TAVARES, Luís Henrique Dias. 0 processo das soluções brasileiras no exemplo do tráfico negreiro. Revista de História, v. 35, n. 72, p. 531, 1967.

41 Pequenos veleiros de transporte de carga. "Um sumaca ou bergantim, que pagava, em 1808, de $20 \$ 000$ a
Bahia, Europa, Conceição etc.) que transportavam passageiros e gêneros, inclusive escravos, inserindo-se como negociante importador e exportador (Diário do Rio de Janeiro, 27 de fevereiro de 1838, p. 9). Foi ele, também acionista do "novo Banco do Brasil"42 que estava sendo criado (Diário do Rio de Janeiro, 25 de outubro de 1855, p. 2). Nada pude encontrar sobre a sogra de Amélia, o que é natural face às fontes que usei: os jornais. Naquele momento, pouquíssimas mulheres tinham seus nomes publicizados, exceto se vinculados ao marido, ou em obituários e/ou anúncios fúnebres.

João Francisco da Costa Júnior, marido de Amélia, principia sua vida profissional como 3o escriturário da Alfândega ${ }^{43}$ (Almanak Laemmèrt, Administrativo, Mercantil e Industrial, 1891, p. 48) aposentando-se em 1921, como 1o escriturário (Correio da Manhã, 10 de agosto de 1921, p. 3). Foi ele, também, Procurador da Caixa Emancipadora Nossa Senhora da Glória (Gazeta de Notícias, 7 de abril de 1884, p. 1) e Fiscal do Imposto do Fumo e Bebidas (Cidade do Rio, 3 de setembro de 1897, p. 1). Participava o casal de inúmeras atividades sociais publicizadas nos jornais (A Notícia, 11/12

$40 \$ 000$ para despacho para as costas d'Africa, passou a pagar $50 \$ 000$ e $100 \$ 000 "$. MAIA, José Joaquim da Silva. Memórias históricas e philosophicas sôbre o Brasil. In: Minerva Brasiliense, Jornal de Sciencias, Lettras e Artes, vol. 2, Rio de Janeiro, Minerva Brasiliense, 1844. p. 582

42 O novo Banco do Brasil teve a liderança da criação e reorganização de Irineu Evangelista de Souza, Barão e depois Visconde de Mauá. Dois anos depois, na primeira fusão bancária da história brasileira, o Banco do Brasil, de Mauá, funde-se com o Banco Comercial do Rio de Janeiro. Para saber sobre a história desta instituição ver: CARDOSO, José Luís. Novos elementos para a história do Banco do Brasil (1808-1829): crónica de um fracasso anunciado. Revista Brasileira de História, v. 30, p. 167-192, 2010; SIMONSEN, Roberto C. História Econômica do Brasil: 1500-1820. São Paulo; Rio de Janeiro; Recife: Companhia Editora Nacional, 1937; RODRIGUES, Lea Carvalho. Metáforas do Brasil: demissões voluntárias, crise e rupturas no Banco do Brasil. São Paulo: Annablume, 2004; PRADO JR, Caio. História Econômica do Brasil. São Paulo: Brasiliense, 2017.

43 Promovido a 2o escriturário em 1899 (Almanak Laemmèrt, 1899, p. 131). Disponível em: <http:// www45.bb.com.br/docs/ri/ra2010/port/ra/02.htm\#3>. Acesso em: 8 set. 2018. 
de junho de 1902, p. 2; O Paiz, 9 de abril de 1910, p. 5; Gazeta de Notícias, 3 de janeiro de 1911, p. 4; Jornal do Brazil, 24 de agosto de 1915, p. 8; 0 Paiz, 29 de abril de 1913, p. 3; O Paiz, 16 de abril de 1914, p. 6; Correio da Manhã, 21 de setembro de 1916, p. 4; A Imprensa, 5 de outubro de 1916, p. 5 etc.), dando indícios de ampla rede de sociabilidade. João Francisco ficou gravemente ferido quando do assassinato de Abel de Medeiros Fernandes (Jornal do Commercio, 7 de março de 1897, p. 2), o que, suponho, tenha sido motivo de grande preocupação por parte de Amélia, por envolver parente seu e seu marido. João Francisco faleceu em 1928 (A Manhã, 1o de abril de 1928, p. 4) deixando Amélia viúva.

Amélia e João Francisco tiveram cinco fiIhos: Amélia, batizada na Igreja da Candelária, e falecida ainda criança, em 1894 (O Paiz, 26 de julho de 1894, p. 2; Gazeta de Notícias, 26 de julho de 1894, p. 3); Carlos, falecido criança, em 1895 (Gazeta de Notícias, 9 de novembro de 1895 , p. 2); João, também falecido ainda criança (Gazeta da Tarde, 23 de junho de 1896, p. 1); Noemia Fernandes da Costa e Anibal Fernandes da Costa, que se formou engenheiro e foi professor do Instituto de Educação. ${ }^{44}$

Amélia faleceu em 28 de janeiro de 1935 (Correio da Manhã, 30 de janeiro de 1935, p. 6; 27 de fevereiro de 1935, p. 13) “saindo o féretro de sua residência, à rua Alzira Brandão, no 130, para o cemitério de S. João Batista, na cidade do Rio de Janeiro" (Jornal do Brasil, 30 de ja-

44 Sucedâneo da Escola Normal da Corte, onde estudara sua mãe, Amélia. Este educandário, uma escola de formação de professores primários centenária, teve, ao longo dos anos, várias designações: Escola Normal da Corte, Escola Normal da Capital Federal, Escola Normal do Distrito Federal, Instituto de Educação, Instituto de Educação do Estado da Guanabara, Instituto de Educação do Estado do Rio de Janeiro e, atualmente, desde 1998, Instituto Superior de Educação do Rio de Janeiro. Neste educandário encontra-se o Centro de Memória, depositário das fontes acadêmicas sobre Amélia, às quais agradeço a cessão e digitalização para pesquisa à Professora Marlúcia Neri, atual coordenadora, e à Universidade do Estado do Rio de Janeiro (CEPUERJ/UERJ), pela abertura dos microfilmes daquele acervo, sem nenhum ônus. neiro de 1935, p. 12). Teceu o Correio da Manhã de 30 de janeiro de 1935, à p. 6, a seguinte referência obituária sobre Amélia que qualifica sua vida: "Era a falecida uma das mais distintas professoras e pela sua infinita bondade era venerada por sua família como por todos que a conheciam".

\section{Conclusão}

Ensinou-me Ginzburg (1989, p. 177) que "se a realidade é opaca, existem zonas privilegiadas - sinais, indícios - que permitem decifrá-la", o que optei fazer para concluir que Amélia Fernandes da Costa era uma professora primária, como tantas outras, afetuosa aos alunos, como dela lembrou-se Antenor Nascentes e o pequeno obituário do Jornal do Brasil, com uma grande e diversificada rede de sociabilidade, seu capital social. Esta rede, mobilizada por ela, permitiu que fosse inserida no projeto de modernização do ensino primário em curso naquele momento de mudança de regime político, que previa uma reforma educacional alicerçada em modelos europeus. O relacionamento de Amélia através da própria família, ou da família do marido, que conservava contatos em vários níveis hierárquicos na Instrução Pública, a legitimou no campo educacional por ter participado da viagem em 1890. Para que isso pudesse ocorrer foi alçada de adjunta a professora, visto que a escolha dos viajantes selecionados por certo recairia sobre professores, não em adjuntos. Amélia era uma muIher rica, casada com um homem rico, que não precisava do cargo, não precisava das benesses de uma viagem comissionada, mas talvez lhe aprouvesse, assim o percebo, a legitimidade que a viagem the proporcionaria, o que realmente ocorreu, e que rendeu a ela, como capital social, a legitimação profissional que se estendeu à imprensa. A impossibilidade de biografá-la em pesquisas anteriores sobre a 
primeira viagem pedagógica comissionada da república, suponho, ocorreu inicialmente pela escolha de fontes a serem consultadas pelos historiadores, pois que, infelizmente, as publicações biobibliográficas comumente não privilegiam mulheres, e pela troca de nomes de Amélia pelo matrimônio, o que pude descobrir apenas pelos jornais. Por ser uma professora comum, no século XIX, há lapsos quanto ao ano em que nasceu.

\section{Referências}

ALMEIDA, Jane Soares de. Mulher e educação: a paixão pelo possível. São Paulo: Editora UNESP, 1998.

As professoras no século XX: as mulheres como educadoras da infância. In: CONGRESSO BRASILEIRO DE HISTÓRIA DA EDUCAÇÃO, "Educação Escolar em Perspectiva Histórica”, 3., 2004, Curitiba. Anais... Curitiba: PUC-PR; SBHE, 2004.

ARQUIVO NACIONAL DO BRASIL. Relatórios do Ministro e Secretário de Negócios do Império. Anexo: Relatório dos Sucessos mais Notáveis do Ano Letivo da Escola Normal da Corte. 1880 a 1889.

BIBLIOTECA NACIONAL. Hemeroteca. Periódicos. Disponivel em: <http://bndigital.bn.gov.br/hemeroteca-digital/>. Acesso: 10 set. 2018.

A Época, 28 de junho de 1913.

Imprensa, 5 de outubro de 1916.

A Manhã, 1 de abril de 1928.

A Nação: jornal político, comercial e literário (RJ), 4 de agosto de 1873.

A Notícia, 11/12 de junho de 1902.

A Reforma: órgão democrático (RJ), 10 de julho de 1875.

Cidade do Rio, 17 de janeiro de 1888; 17 de fevereiro de 1888; 16 de outubro de 1890; 1 de dezembro de 1895; 1 - de dezembro de 1895; 18 de maio de 1895; 9 de maio de 1896; 1 de dezembro de 1896; 3 de setembro de 1897 .
Correio da Manhã, 21 de setembro de 1916; 10 de agosto de 1921; 30 de janeiro de 1935; 27 de fevereiro de 1935.

Correio Mercantil e Instructivo, Político, Universal, 9 de novembro de 1857; 30 de julho de 1860; 10 de janeiro de 1862; 10 de julho de 1862; abril, 1893; 27 de maio de 1863; 14 de agosto de 1865; s/d fevereiro de 1888.

. Diário Commercial, 26 de maio de 1890.

Diário de Notícias, 12 de dezembro de 1888; 16 de dezembro de 1891; 13 de maio de 1894.

Diário do Commercio, 28 de agosto de 1862; 23 de junho de 1891; de 16 de dezembro de 1891.

Diário do Brazil, 30 de setembro de 1884.

Diário do Rio de Janeiro, 27 de fevereiro de 1838; 13 de outubro de 1855; 25 de outubro de 1855; 20 de março de 1872.

Diário Portuguez, 29 de agosto de 1885.

Gazeta da Tarde, 22 de novembro de 1883; 22 de janeiro de 1884; 29 de setembro de 1884; 16 de junho de 1888; 1ㅇ de novembro de 1890; 10 de dezembro de 1890; 20 de junho de 1891; 4 de janeiro de 1892; 23 de junho de 1896; 23 de novembro de 1897; 3 de janeiro de 1898.

Gazeta de Notícias, 7 de abril de 1884; 5 de fevereiro de 1889; 21 de março de 1889; 3 de maio de 1889; 5 de fevereiro de 1890; 21 de março de 1893; 26 de julho de 1894; 9 de novembro de 1895; 12 de março de 1898; 3 de janeiro de 1911.

Jornal do Brazil, 11 de março de 1895; 5 de setembro de 1896; 24 de agosto de 1915; 8 de abril de 1931; 30 de janeiro de 1935.

Jornal do Commercio, 25 de abril de 1855; 29 de abril de 1874; 4 de maio de 1880; 22 de novembro de 1883; 26-27 de junho de 1883; 10 de junho de 1888; 13 de junho de 1888; 16 de junho de 1888; 22 de janeiro de 1889; 7 de maio de 1891; 8 de maio de 1891; 13 de novembro de 1896; 7 de março de 1897; 22 de março de 1898.

Novidades, 19 de março de 1887. 
O Paiz, 29 de janeiro de 1894; 26 de julho de 1894; 18 de dezembro de 1894; 27 de abril de 1885; 9 de setembro de 1895; 30 de dezembro de 1887; 4 de janeiro de 1898; 9 de abril de 1910; 29 de abril de 1913; 16 de abril de 1914.

O Tempo, 18 de dezembro de 1983; 21 de novembro de 1893.

BORGES, Angélica. Nem tudo que luz é ouro: representações docentes em relatórios de uma viagem à Europa (1980-1982). In: CONGRESSO BRASILEIRO DE HISTÓRIA DA EDUCAÇÃO, 4., 2006, Goiânia. Anais... Goiânia: SBHE, 2006.

BOURDIEU, Pierre. Economia das trocas simbólicas. Introdução, organização e seleção de Sergio Micheli. São Paulo: Perspectiva, 2007.

Escritos de Educação. Organização de Maria Alice Nogueira e Afrânio Catani. Petrópolis, RJ: Vozes, 1998.

Le capital social. Actes de la Recherche en Sciences Sociales, v. 31, p. 2-3, jan. 1980.

BUENO, Belmira Oliveira; CHAMLIAN, Helena Coharik; SOUSA, Cynthia Pereira de.; CATANI, Denice Barbara. Histórias de vida e autobiografias na formação de professores e profissão docente (Brasil, 1985-2003). Educação e Pesquisa, São Paulo, v. 32, n. 2, p. 385410, mai./ago. 2006.

BUFFA, Ester. Apresentação. In: ALMEIDA, Jane Soares de. Mulher e educação: a paixão pelo possível. São Paulo: Editora UNESP, 1998. p. 15-16.

CENTER FOR RESEARCH REPORTS. Ministerial Reports. Ministério do Império. Disponível em:<http: / / www-apps.crl.edu/brazil/ministerial>. Acesso em: 12 ago. 2018

Atos de 17 e 25 de julho.

Decretos de 6 e 10 de julho de 1867.

. Decreto de 20 de novembro de 1883.

Decreto de 6 de junho de 1888.

Portaria de 20 de outubro de 1855. Approva e Manda que se observe, para execução do paragrapho 8o do Art. 3o do Regulamento, que baixou c/o
Decreto № 1331-A, de 17 de Fevereiro de 1854, o Regimento Interno para as Escolas de Instrucção Primaria. (Collecção das Decisões do Governo do Imperio do Brasil, Tomo XVIII, caderno 10o. p. 344-352).

. Relatório da Instrução Primária e Secundária, 1873.

pério. 1877.

. Relatório da Repartição dos Negócios do Im-

. Relatório da Instrução Primária e Secundária, 1882.

. Relatório da Instrução Primária e Secundária, 1883.

BRAZILIAN GOVERNMENT DOCUMENTS. Disponível em: <http://www-apps.crl.edu/brazil/almanak>. Acesso em: 12 ago. 2018.

. Almanak Laemmèrt, Administrativo, Mercantil e Industrial, 1875; 1877; 1879; 1891; 1899. Disponível em: <http://www-apps.crl.edu/brazil/almanak>. Acesso em: 12 ago. 2018.

CENTRO DE MEMÓRIA DO INSTITUTO SUPERIOR DE EDUCAÇÃO DO RIO DE JANEIRO. Livro da Porta.

Microfilmes SRAE 001 e 002 Instituto de Educação.

. Revista Pedagógica Tomos I e II.

CONCEIÇÃO, Gabriel Luis da e SILVA, Maria Amélia Leme da. Circulação de propostas internacionais sobre o ensino dos saberes geométricos: Rio de Janeiro e São Paulo, final do século XIX. Revista Educação Matemática em Foco, Universidade Estadual da Paraíba (UEPB), v. 7, n. 1, p. 2-25, 2018.

CPDOC/FGV. Leôncio Correia. Disponível em: <https://cpdoc.fgv.br/sites/default/files/verbetes/primeira-republica/CORREIA,\%20Le\%C3\%B4ncio.pdf>. Acesso em: 12 ago. 2018.

DELORY-MOMBERGER, Christine. Formação e socialização: os ateliês biográficos de projeto. Educação e Pesquisa, São Paulo, v. 32, n. 2, p. 359-371, mai./ ago. 2006.

DOSSE, François. 0 desafio biográfico: escrever uma vida. Tradução de Gilson César Cardoso de Souza. 
São Paulo: Editora da Universidade de São Paulo, 2009.

FERRAZ, Paula Ribeiro. O Império em tempos de conciliação: atores, ideias e discursos (1848-1857). Belo Horizonte: Editora Fino Traço, 2016.

GARCIA, Inára de Almeida. Um professor em dois mundos: a viagem do professor Luiz Augusto dos Reis à Europa (1891). 2011. 260 f. Tese (Doutorado em Educação) - Faculdade de Educação, Universidade de São Paulo - USP, São Paulo, 2011.

GERBOVIC, Tathiane. Informação e poder econômico: viajantes e relatos de viagens na São Paulo oitocentista. In: Simpósio Nacional de História, 24., 2007. Anais... Associação Nacional de História - ANPUH, 2007. p. 1-10 Disponivel em: <http://snh2007.anpuh. org/resources/content/anais/Tathiane\%20Gerbovic.pdf>. Acesso: 03 mai. 2018.

GINZBURG, Carlo. Mitos, emblemas e sinais: morfologia e história. Tradução de Frederico Carotti. São Paulo: Cia. das Letras, 1989.

O fio e os rastros: verdadeiro, falso, fictício. Tradução de Rosa Freire d'Aguiar e Eduardo Brandão. São Paulo: Cia. das Letras, 2007.

GONDRA, José Gonçalves. O Veículo de Circulação da Pedagogia Oficial da República: a Revista Pedagógica. Brasil. Est. Pedagógicos, Brasília, v. 78, n. 188, 189 e 190, jan./dez. 1997. p. 374-39.

GONDRA, José Gonçalves; SCHUELER, Alessandra Frota Martinez. Olhar o outro, ver a si: um professor primário no "Velho Mundo" (1890-1892). Revista Brasileira de História da Educação, v. 22, p. 87-112, 2010.

GUSSI, Alcides Fernando. Reflexões sobre os usos de narrativas biográficas e suas implicações epistemológicas entre a Antropologia e a Educação. In: REUNIÃO BRASILEIRA DE ANTROPOLOGIA, 26., 2008, Porto Seguro. Anais... Porto Seguro, 2008.

KEHL, Maria Rita. Deslocamentos do feminino. 2. ed. Rio de Janeiro: Imago, 2008.

LEITE, M. L. M. Livros de viagem (1803/1900). Rio de Janeiro: Editora da UFRJ, 1997.
MAIA, Ludmila de Souza. Viajantes de saias: escritoras e ideias antiescravistas numa perspectiva transnacional (Brasil, século XIX). Revista Brasileira de História, v. 34, n. 68, p. inicial-final, p. 61-81, 2014.

MIGNOT, Ana Chrystina Venancio; SILVA, Alexandra Lima da. Tão longe, tão perto: escrita de si em relatórios de viagens. Educação em Revista, Belo Horizonte, v. 27, n. 01, p. 435-458, abr. 2011.

NÓVOA, António. Formação de professores e profissão docente. Disponível em: <https://core.ac.uk/ download/pdf/12424596.pdf>. Acesso em: 21 ago. 2018.

PINTO, Inara de Almeida Garcia. Um professor em dois mundos: a viagem do professor Luiz Augusto dos Reis à Europa (1891). 2011. 259 f. Tese (Doutorado em Educação) - Faculdade de Educação, Universidade de São Paulo (USP), São Paulo, 2011. Disponível em: <www.teses.usp.br/teses/disponiveis/48/48134/tde-16022012-103537/pt-br.php>. Acesso em: 01 abr. de 2017.

SANTOS, Heloisa Helena Meirelles dos. Congregação da Escola Normal: da legitimidade outorgada à legitimidade (re)conquistada (1880-1910). 2011. 212 f. Dissertação (Mestrado em Educação) - Programa de Pós-Graduação em Educação (PROPEd), Universidade do Estado do Rio de Janeiro (UERJ), Rio de Janeiro, 2011. Disponível em: <http://heloisahmeirelles.blogspot.com/p/congregacao-da-escola-normal-da.html>. Acesso em: 12 set. 2018.

SCHUELER, Alessandra Frota Martinez de. Crianças e escolas na passagem do Império para a República. Rev. Bras. Hist., v. 19, n. 37, p. 59-84, 1999.

Professores primários como intelectuais da cidade: um estudo sobre produção escrita e sociabilidade intelectual (Corte imperial, 1860-1889). Revista de Educação Pública, v. 16, n. 32, p. 131-144, set./dez. 2007.

. Escolas Primárias e Professores na Corte Imperial: educação escolar como objeto da História Social. Revista Momento, Fundação Universidade do Rio Grande do Sul, v. 18, n. 1, p. 11-33, 2008.

SCHUELER, Alessandra Frota Martinez de.; GONDRA, José Gonçalves. Olhar o outro, ver a si: um professor 
primário brasileiro no "Velho Mundo" (1890-1892). Revista Brasileira de História da Educação, n. 22, p. 87-112, jan./abr. 2010.

SIRINELLI, Jean-François. Os intelectuais. In: RÉMOND, René. (Org.). Por uma história política. Rio de Janeiro: UFRJ; FGV, 1996. p. 9-12.

SOARES, Jeferson da Costa. As Contribuições de Joseph Herman à Educação Brasileira no Período Imperial. Hist. Educ., Porto Alegre, v. 22 n. 54, p. 318333, jan./abr. 2018.
VELLOSO, Mônica Pimenta. As tradições populares na Belle Èpoque carioca. Rio de Janeiro: FUNARTE, 1988.

VILELA, Amanda. Ramiz Galvão, Benjamin Franklin. Diretor Geral de Instrução Pública Municipal. Disponível em: <http://expagcrj.rio.rj.gov.br/ramiz-galvao -benjamin-franklin/>. Acesso em: 8 nov. 2018.

Recebido em: 06/02/2019 Aprovado em: 18/04/2019

Heloisa Helena Meirelles dos Santos é Doutora e Mestre em Educação (UERJ), tem Pós-Doutorado em Educação (UERJ). É pesquisadora do Programa de Pós-Graduação em Educação (PROPEd) na linha de pesquisa Instituições, Prăticas Educativas e História, área de Memória e Cultura, na Universidade do Estado do Rio de Janeiro (UERJ). e-mail: helohmei@ gmail.com

Rua São Francisco Xavier, 524, sala 12.037, Maracanã, Rio de Janeiro, RJ CEP: 20550-900. Telefones: (21)2565-6362 (21)98781-6362 